\title{
DETERMINANTS OF THE QUALITY OF LIFE IN MUNICIPALITIES OF KIELCE DISTRICT
}

\author{
Katarzyna BRZOZOWSKA-RUP ${ }^{1 *}$, Roksana CZAJA², Agnieszka PIOTROWSKA-PIĄTEK ${ }^{3}$ \\ ${ }^{1}$ Kielce University of Technology, Statistical Office in Kielce; krup@tu.kielce.pl, \\ ORCID: 0000-0003-1231-8027 \\ ${ }^{2}$ Kielce University of Technology, r.czaja@stat.gov.pl, ORCID: 0000-0002-8685-0916 \\ ${ }^{3}$ Kielce University of Technology, Statistical Office in Kielce; apiotrowska@tu.kielce.pl, \\ ORCID: 0000-0002-6620-5485 \\ * Correspondence author
}

Purpose: Identifying the factors that significantly affect the quality of life of the residents of municipalities of the Kielce poviat based on a synthetic indicator.

Design/methodology/approach: The method used in the paper is create a synthetic indicator designed using a taxonomic method and the estimation of the logistic regression model. Data of the Central Statistical Office concerning the years 2014-2018 were used in the calculations.

Findings: The obtained values of the TMR (Total Material Requirement) indicator suggest that in the Kielce poviat the quality of life of the residents of individual municipalities is very diverse. At the same time, a common positive tendency is observed, manifested in the trend indicating an improvement in the quality of life in each of the municipalities in the examined period. The constructed indicator was used to estimate the regression model for cross-sectional data from 2018.

Originality/value: The estimated models allowed to formulate conclusions concerning the impact of particular explanatory variables on the diagnosed level of quality of life in the surveyed municipalities.

Keywords: quality of life, logistic regression, Hellwig's method.

Category of the paper: research paper, literature review.

\section{Introduction}

Quality of life is currently a popular topic and has a special place in the dynamically developing world. Similarly to social and economic development, it is diverse not only in individual regions of the world, but also within countries and even regions or smaller territorial 
units. That is why it is the subject of interest of scientists from many disciplines, including the representatives of social and medical sciences and employees of public institutions.

Forming an explicit definition of this concept is not an easy task, since the quality of life is made up of biological, economic, psychological, sociological and even philosophical elements. The most commonly used measure of the degree of social and economic development of individual countries is a synthetic Human Development Index (HDI), which has been calculated annually since 1990. The current definition of the HDI index refers to the assessment of health, access to knowledge and the material aspect of human life. The index calculated using the geometric mean of standardized indices in the areas mentioned above allows for regular comparison of the quality of life in many countries, which in turn allows for observation and analysis of emerging differences.

\section{Quality of life as a pluralistic concept of an interdisciplinary nature}

An increase in interest in the concept of quality of life has been observed since the eighties of the 20th century. The separation of the notions of "economic growth" from the "level of country development" resulted in the introduction of the term of sustainable development. The existing measures of economic growth were based on the factual sphere of the economy, so the search for indicators that would also include qualitative aspects of well-being began (Cieślik, 2008). The primary goal of human activity is to increase the quality of life and reduce the disproportion in its level in territorial and social perspective. The main task of the emerging socio-economic development strategies is the elimination of poverty and social exclusion (Sompolska-Rzechuła, 2017).

Many of contemporary public actions are based on the sustainable development strategy, which assumes "fair and dignified sharing of the world, a sustainable way of life and equality of generations in access to beauty and environmental resources" (Panek, 2007). The main element of the strategy is not only the current quality of human life, but also that of future generations (Nowak, 2018). The diagnosis of the social situation based on the study of the relationship between economic and social phenomena allows to assess the social consequences of economic development. These studies are carried out by means of direct and/or online surveys, statistical data collected in the course of other community surveys, and the mixed method. The main research tools are social indicators and measures (Panek, 2007).

Among the representatives of economic sciences, quality of life is usually defined as a combination of welfare and well-being of an individual. Welfare is the stock of consumer goods and financial means available to the individual. It is therefore directly related to the concept of quality of life - the level of living. In 1954, the UN Commission of Experts proposed the following definition of this term: "The concept of the level of living encompasses the 
entirety of people's actual living conditions and the degree to which their needs are materially and culturally satisfied by means of a flow of both paid goods and services, as well as those from social funds" (Kozera \& Kozera, 2011). A similar definition of the level of living was presented by C. Bywalec. The quoted author believes that it is the degree of satisfaction of human needs, resulting from the consumption of material goods and services and the use of values of the natural and social environment (Sompolska-Rzechuła, 2017). Well-being, on the other hand, is primarily related to the emotional aspect. It can therefore be said that it is related to spiritual values, dignity, and moral and lawful conduct, without any tendency to possess excessive material goods" (Panek, 2007).

E. Allardt made an attempt to integrate the above concepts. The key to his research was to distinguish two dimensions: the level of living and the quality of life, each of which was assessed in terms of welfare and happiness. In the presented concept, the level of life is material living conditions (having), and the quality of life is interpersonal relations (loving) and selffulfillment (being). Welfare is an objective assessment of individual issues, while happiness is a subjective opinion - the feeling of satisfaction/dissatisfaction in a given sphere (Peletewicz \& Drabowicz, 2016).

The concepts of the level of living and the quality of life involve needs, both material and non-material. People assess the quality of life positively when their needs are fully satisfied. A. Maslow's theory of needs classifies human needs by dividing them into lower-order needs (which are met first) and higher-order needs. In the case of a low degree of satisfaction of needs, a person feels a state of deprivation or deficiency, while a high degree of satisfaction of needs causes a feeling of satisfaction and gratification (Peletewicz \& Drabowicz, 2016).

The presented theory of needs concerns mainly the individual, but more and more often it appears in a developed form as a concept of social needs satisfied by functional institutional needs.

Public statistics distinguish four interrelated categories relating to this problem:

- living conditions, which are the entire infrastructure of society. This category contains the material condition, the condition of the environment in the near and distant surroundings, the professional situation and state of health. Living conditions are described using objective indicators;

- the level of living is the degree of satisfaction of needs through consumption of material and non-material goods. The description of the level of living assumes the use of objective measures;

- the quality of life involves all the elements of human life related to its existence not only material and non-material goods, but also social bonds and emotions. The analysis of the quality of life is therefore based on the assessment of the subjective aspects of life; 
- dignity of life consists in minimizing the feeling of deprivation, which is a consequence of changing living conditions resulting from unstable economic conditions (Gotowska, 2013).

It should be noted that the elements that make up the quality of life in the broad sense are subject to constant change. Changes in the natural, socio-economic and cultural environment cause new needs to emerge (Sompolska-Rzechuła, 2017).

In this article, the adopted methodical approach combines the concepts of the level of living and quality of life, taking into account economic factors that determine the degree of satisfaction of residents' needs and objective factors of their socio-economic situation.

\section{Review of research on the quality of life conducted by the Statistics Poland}

The importance and multi-faceted nature of the issue of quality of life is reflected in official statistical surveys. The concept of measuring this phenomenon adopted by the Statistics Poland refers both to international recommendations (e.g. OECD, Eurostat) and to the rich tradition of Polish research in this field. The broadly understood living conditions include such areas as: material living conditions, health, education, economic activity, free time and social relations, security, quality of the state and basic rights, as well as the quality of the natural environment in the place of residence. The measurement of subjective welfare, on the other hand, includes the perceived quality of life as well as elements concerning emotional states and the system of values.

Statistics Poland uses the results of many surveys for developing and calculating the indicators of the quality of life, such as:

- Social Cohesion Surveys (a cyclical, representative household survey; the data collected during this survey allows for the analysis of comprehensive assessments of the quality of life, understood as a category taking into account economic and social aspects and evaluated using both objective and subjective indicators).

- European Union Statistics on Income and Living Conditions (an annual, representative household survey, carried out since 2005; the primary objective of this survey is to provide comparable for the European Union countries data on the broadly defined living conditions of the population).

- Family Budget Surveys (an annual, representative household survey carried out since 1957; the results of this survey allow the analysis of material aspects of the population's living conditions, as well as the assessment of the impact of various factors on the level and differentiation of the living conditions of groups of households).

- Labor Force Survey (a continuous, representative survey, carried out since 1992; the aim of this survey is to assess the situation of economic activity of the population). 
- European Health Interview Survey (a cyclical, representative survey, conducted for the first time in 2009; the objective of this survey is to assess the health condition of the population of Poland, including subjective overall assessment of physical and mental health).

In the analyses of the quality of life carried out by the Statistics Poland, the results from the above surveys are complemented by data from other surveys, censuses, statistical reporting and administrative sources (Główny Urząd Statystyczny, 2017).

\section{Research methodology}

The aim of this article is to identify the factors that significantly affect the quality of life of the residents of the municipalities of the Kielce poviat. For the purpose of its implementation a synthetic indicator of the quality of life was constructed, based on selected features (Table 1). A commonly used indicator of quality of life and level of living (TMR development indicator) created by Z. Hellwig was used. The analysis covered 19 municipalities of the Kielce poviat (according to the administrative division as of 31 December 2018). The data from the Statistics Poland concerning the years 2014-2018 were used for calculations.

The selection of the studied areas referring to the quality of life and construction of measures was based on formal, substantive and statistical criteria. The following analytical categories have been distinguished (table 1): housing conditions; demography, economic activity and education; quality of the natural environment; recreation and culture; institutional capacity to meet the needs of society.

The absence of a category referring to interpersonal relations, belonging to the local community and general mood is caused by the lack of data in this respect (cf.: Włodarczyk, 2015).

\section{Table 1.}

Variables used to create a synthetic indicator of the quality of life in the municipalities of the Kielce poviat

\begin{tabular}{|l|l|l|l|l|l|}
\hline \multicolumn{2}{|c|}{ Housing conditions } & + & $W_{23}$ & $\begin{array}{l}\text { percentage of children in pre-school education } \\
\text { aged 3-5 years (in \%) (S) }\end{array}$ \\
\hline+ & $W_{1}$ & usage of the sewerage system (in \%) (S) & + & $W_{24}$ & marriages per 1,000 population (S) \\
\hline+ & $W_{2}$ & usage of gas (in \%) (S) & - & $W_{25}$ & birth rate per 1,000 population \\
\hline+ & $W_{3}$ & $\begin{array}{l}\text { density of the water supply network (in km } \\
\text { per 100 km2) (S) }\end{array}$ & \multicolumn{3}{|c|}{ Quality of the natural environment } \\
\hline- & $W_{4}$ & $\begin{array}{l}\text { bathrooms in apartments in rural areas (in \%) } \\
\text { bath }\end{array}$ & + & $W_{27}$ & $\begin{array}{l}\text { collection and disposal of waste }- \text { septic tanks } \\
\text { (D) }\end{array}$ \\
\hline- & $W_{5}$ & $\begin{array}{l}\text { central heating in apartments in rural areas } \\
\text { (in \%) }\end{array}$ & + & $W_{28}$ & $\begin{array}{l}\text { collection and disposal of waste }- \text { onsite } \\
\text { wastewater treatment systems (S) }\end{array}$ \\
\hline+ & $W_{6}$ & $\begin{array}{l}\text { average usable floor area per 1 person in an } \\
\text { apartment (in m2) (S) }\end{array}$ & - & $W_{29}$ & water consumption per capita (in m3) \\
\hline
\end{tabular}


Cont. table 1 .

\begin{tabular}{|c|c|c|c|c|}
\hline & $W_{7}$ & average number of rooms in 1 apartment & $+W_{30}$ & $\begin{array}{l}\text { mixed waste collected per year per capita (in } \mathrm{kg} \text { ) } \\
\text { (D) }\end{array}$ \\
\hline & $W_{8}$ & average number of people per apartment & $+W_{31}$ & Reforestation and afforestation (in ha) (S) \\
\hline & $W_{9}$ & $\begin{array}{l}\text { new residential buildings per } 1,000 \\
\text { population }\end{array}$ & $+W_{32}$ & share of forest land in the total area (in \%) (S) \\
\hline & $W_{10}$ & $\begin{array}{l}\text { average duration of construction of new } \\
\text { residential buildings (in months) (D) }\end{array}$ & $W_{33}$ & logging - large logs (in $\mathrm{m} 3$ ) \\
\hline & Demo & graphy, economic activity and education & & Recreation and culture \\
\hline & $W_{11}$ & $\begin{array}{l}\text { share of the registered unemployed in the } \\
\text { number of people of working age (in \%) (D) }\end{array}$ & & \\
\hline & $W_{12}$ & $\begin{array}{l}\text { share of people of pre-working age in the } \\
\text { total population (in \%) }\end{array}$ & $W_{34}$ & population per 1 library \\
\hline & $W_{13}$ & $\begin{array}{l}\text { share of people of working age in the total } \\
\text { population }(\%)\end{array}$ & $+W_{35}$ & library book collection per 1,000 population (S) \\
\hline & $W_{14}$ & $\begin{array}{l}\text { share of people of post-working age in the } \\
\text { total population (in \%) (D) }\end{array}$ & $+W_{36}$ & $\begin{array}{l}\text { book collection borrowing per } 1 \text { reader (in } \\
\text { books) }(\mathrm{S})\end{array}$ \\
\hline & $W_{15}$ & $\begin{array}{l}\text { internal migration balance per } 1,000 \\
\text { population }(\mathrm{S})\end{array}$ & $+W_{37}$ & cultural centers, community centers (S) \\
\hline & $W_{16}$ & $\begin{array}{l}\text { number of working people per } 1,000 \\
\text { population }\end{array}$ & $+W_{38}$ & average number of beds per tourist facility (S) \\
\hline & $W_{17}$ & $\begin{array}{l}\text { national economy entities per } 10,000 \\
\text { inhabitants of working age }\end{array}$ & \multicolumn{2}{|c|}{ Institutional capacity to meet the needs of residents } \\
\hline & $W_{18}$ & $\begin{array}{l}\text { share of children under } 17 \text { for whom parents } \\
\text { receive child allowance in the total number of } \\
\text { children of that age (in \%) }\end{array}$ & $W_{39}$ & $\begin{array}{l}\text { share of expenditures on public roads in total } \\
\text { expenditures (in \%) (S) }\end{array}$ \\
\hline & $W_{19}$ & $\begin{array}{l}\text { beneficiaries of community social assistance } \\
\text { per } 10,000 \text { population }\end{array}$ & $+W_{40}$ & $\begin{array}{l}\text { out-patient health care - medical advice per } \\
1,000 \text { population }(\mathrm{S})\end{array}$ \\
\hline & $W_{20}$ & $\begin{array}{l}\text { share of beneficiaries of community social } \\
\text { assistance in the total population (in \%) (D) }\end{array}$ & $+W_{41}$ & municipality income per capita (in PLN) (S) \\
\hline & $W_{21}$ & $\begin{array}{l}\text { students per } 1 \text { division in primary schools } \\
\text { (people) }(\mathrm{N})\end{array}$ & $+W_{42}$ & $\begin{array}{l}\text { municipality expenditures under Chapter } 700- \\
\text { Housing (in PLN) (S) }\end{array}$ \\
\hline & $W_{22}$ & $\begin{array}{l}\text { students per } 1 \text { division in secondary schools } \\
\text { (people) }(\mathrm{N})\end{array}$ & $W_{43}$ & Municipality housing stock - social housing \\
\hline
\end{tabular}

Source: author's own study.

Using the above mentioned variables, the selection of the representative measures was made by examining their variability and eliminating the variables strongly correlated with each other. Finally, 26 characteristics (marked with a "+" in table 1) were selected for the synthetic indicator of quality of life. In order to enable mutual comparability of features, their values were standardized.

$$
z_{i j}=\frac{x_{i j}-\bar{x}_{j}}{s_{k}}
$$

where:

$z_{i j}$ - standardized value of the feature $j$ in the unit $i$;

$x_{i j}$-absolute value of the feature $j$ in the unit $i$;

$\bar{x}_{j}$ - arithmetic mean of the feature $j$;

$s_{k}-$ standard deviation of the feature $j$. 
The selected variables were divided into stimulants $(S)$, destimulants $(D)$ and nominants $(N)$. On the basis of data from 2018 the coordinates of the development pattern were determined:

$\varphi_{j}=\max _{i} z_{i j} \operatorname{gdy} j \in S$,

$\varphi_{j}=\min _{i} z_{i j}$ gdy $j \in D$.

Next, taxonomic (Euclidean) distances between individual elements and the pattern object were calculated.

$$
d_{i}=\sqrt{\sum_{j=1}^{m}\left(z_{i j}-\varphi_{j}\right)^{2}}
$$

where:

$z_{i j}$ - normalized, empirical value of the $j$-th variable for the $i$-th object,

$\varphi_{j}$ - normalized value of the $j$-th variable for the pattern.

The last phase consisted in calculating a synthetic measure of development for individual objects:

$$
T M R_{i}=1-\frac{d_{i}}{c_{0}}
$$

where $c_{0}$ was determined in classical approach as follows:

$$
c_{0}=\bar{d}_{o}+2 S_{d}
$$

where:

$\bar{d}_{o}$ - the arithmetic mean of the distances of objects from the pattern,

$S_{d}$-standard deviation of the distances of objects from the pattern.

The calculated indicator takes values in the range $[0 ; 1]$. The higher the quality of life in the analyzed object, the higher the value of the indicator (Panek, 2007).

The obtained results of the indicator of quality of life in the surveyed municipalities in the years 2014-2018 are presented in Figure 1. The municipalities are ranked in descending order according to the value of the indicator. The column diagram presents the values of the indicator for each municipality in the analyzed years. The curve added to the diagram, on the other hand, is the result of combining of time averages in the surveyed period determined for each municipality. 


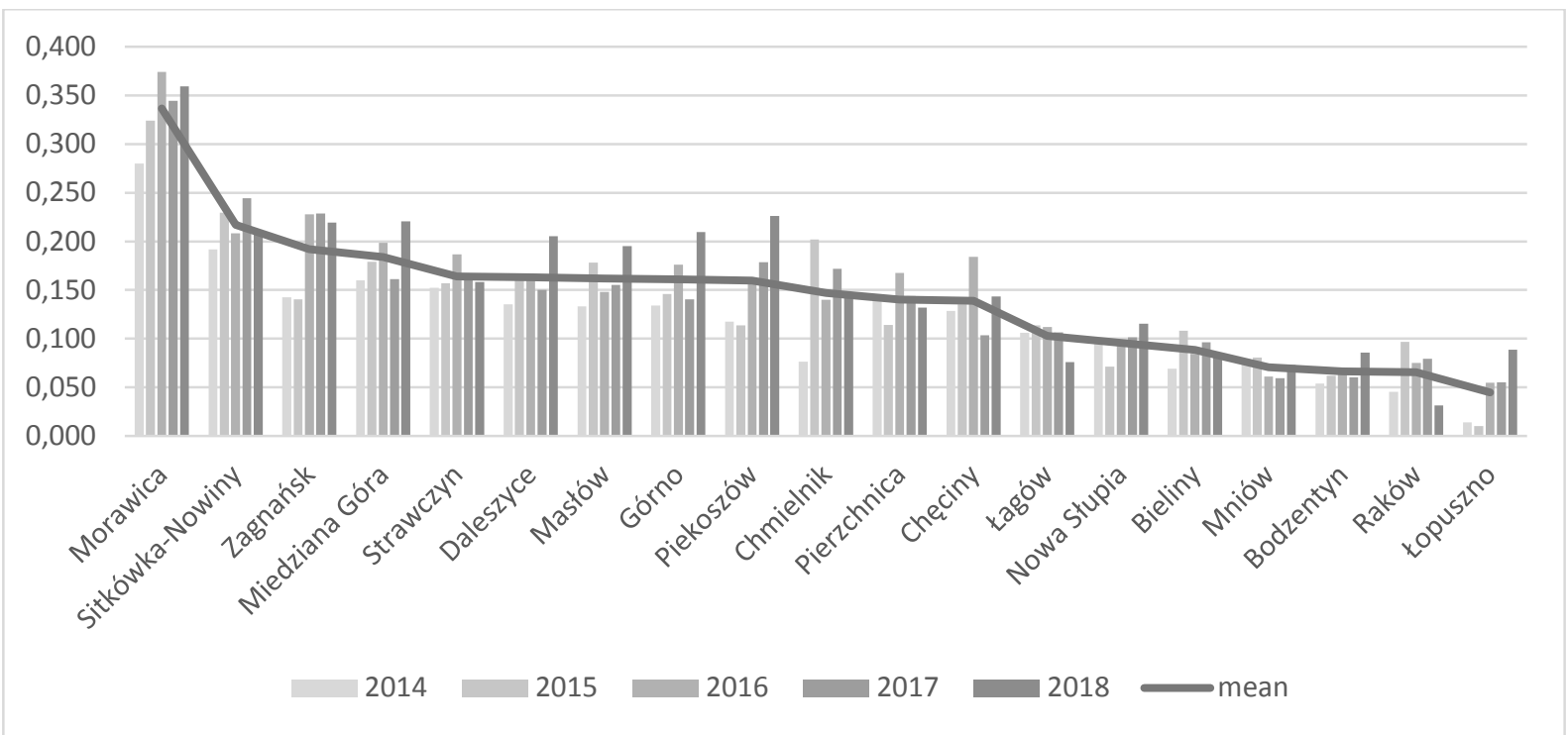

Figure 1. Synthetic indicator of the quality of life in the municipalities of the Kielce poviat in the years 2014-2018. Source: Calculations and own study based on data from: Local Data Bank of the Statistics Poland.

The obtained values of the indicator suggest that in the Kielce poviat the quality of life of the residents of individual municipalities is very diverse. The highest quality of life in the studied period was identified in the municipality of Morawica. The lowest one belongs to the municipality of Łopuszno.

The obtained results of the analysis of quality of life allowed to distinguish four groups of municipalities with different levels of socio-economic development. The ranges were determined on the basis of the average value of the indicator for each municipality in the studied period $\left(\overline{T M R}_{i}, i-\right.$ index for the municipality, $\left.i=1, \ldots, 19\right)$, determined on their basis the median $\left(m_{e}\right)$ and standard deviation $(s)$ (Kielcach, 2016):

- group 1, for which a high level of socio-economic development has been identified $\left(\overline{T M R}_{i} \geq m_{e}+s\right)$ : Morawica, Sitkówka-Nowiny;

- group 2, for which a medium-high level of socio-economic development has been identified $\left(m_{e} \leq \overline{T M R}_{i}<m_{e}+s\right)$ : Zagnańsk, Miedziana Góra, Strawczyn, Daleszyce, Masłów, Górno, Piekoszów, Chmielnik;

- group 3, for which a medium-low level of socio-economic development has been identified $\left(m_{e}-s \leq \overline{T M R}_{i}<m_{e}\right)$ : Pierzchnica, Chęciny, Łagów, Nowa Słupia, Bieliny;

- group 4, for which a low level of socio-economic development has been identified $\left(\overline{T M R}_{i}<m_{e}-s\right)$ : Mniów, Bodzentyn, Raków, Łopuszno.

At the same time, a common optimistic tendency is observed, manifested in the trend indicating an improvement in the quality of life in most of the studied municipalities. A decrease in the value of the proposed indicator is observed only in the municipalities of: Pierzchnica, Łagów, Bieliny and Raków. 


\section{Logistic regression model}

The aim of the presented study was both to measure the quality of life in the surveyed municipalities, as well as to identify the factors of local governments' policies, mainly the category of municipality expenditures, which have a significant impact on improving the quality of life of residents.

Therefore, the next stage of the study was to use the constructed indicator of quality of life as an endogenous variable to estimate the regression model for cross-sectional data from the year 2018.

The study assumed that the quality of life in a given municipality is considered satisfactory when the taxonomic indicator for the municipality exceeds the average level of the quality of life indicator in the studied municipalities in $2018(\bar{y})$. The proposed approach required encoding the dependent variable as a zero-one variable according to the formula:

$$
Z_{t}=\left\{\begin{array}{l}
1, \text { for } y>\bar{y} \\
0, \text { for } y \leq \bar{y}
\end{array}\right.
$$

where value 1 of the variable $Z_{t}$ determines the category of success and the value 0 determines the category of failure.

Since the variable $Z_{t}$ takes only two values (it is not possible to use the classic regression method), the logistic regression model described in the formula below was used for further study:

$$
\operatorname{logit}\left(p_{l}\right)=\ln \left(\frac{p_{l}}{1-p_{l}}\right)=\alpha_{0}+\sum_{i=1}^{k} \alpha_{i} x_{i l}+\varepsilon_{l}
$$

where:

$l=1, \ldots, n, n$ is the number of studied municipalities $(n=19)$;

$x_{i l}$ - the value of the independent variable $X_{i}$ for the $l-t h$ municipality;

$p_{l}$ - probability $p_{l}=P\left(Z_{l}=1 \mid x_{1}, \ldots, x_{k}\right)$;

$\alpha_{i}$-structural parameters of the model;

$\varepsilon_{l}$ - model residuals, also referred to as the error made when estimating the value of the dependent variable (Brzozowska-Rup \& Bednarczyk, 2018).

Logit transformation $\ln \left(\frac{p_{l}}{1-p_{l}}\right)$ defines the logistic function:

$$
p_{l}=\frac{e^{\alpha_{0}+\sum_{i=1}^{k} \alpha_{i} x_{i l}+\varepsilon_{l}}}{1+e^{\alpha_{0}+\sum_{i=1}^{k} \alpha_{i} x_{i l}+\varepsilon_{l}}}
$$


which takes values in the range $[0 ; 1]$. The function reaches boundary values of 0 and 1 in $+\infty$ and $-\infty$. Its values increase slowly from $-\infty$ until they reach the threshold value, above which they increase rapidly, to again slow down the increase as they approach the value of 1 in $+\infty$ (Danieluk, 2010). Details on the theory of logistic regression models can be found, among others, in (David Hosmer, 2000), (Larose, 2012).

The quality of life in a given territory is strongly correlated with social and economic development, which is conditioned by the quality of public policies relating to, among others: health care, social assistance, family support or broadly understood culture. The satisfaction of the needs of the population is realized by proper spending of financial resources by local government units.

Therefore, various categories relating to the following commune expenditures, among others, were adopted as independent variables $(X)$ in the proposed model:

- investment property expenditures on public safety and health care $\left(X_{11}\right)$,

- total property expenditures on school system and education $\left(X_{15}\right)$,

- investment property expenditures on school system and education $\left(X_{16}\right)$,

- total expenditures on health care $\left(X_{17}\right)$,

- expenditures on outpatient treatment $\left(X_{21}\right)$,

- total expenditures on social assistance $\left(X_{25}\right)$,

- expenditures on care services and specialist care services $\left(X_{32}\right)$,

- expenditures on the establishment and operation of nurseries $\left(X_{38}\right)$,

- investment property expenditures on municipal services management and environmental protection $\left(X_{44}\right)$,

- expenditures on maintenance of greenery in cities and municipalities $\left(X_{47}\right)$,

- expenditures on protection of ambient air and climate $\left(X_{49}\right)$,

- subsidies for physical culture $\left(X_{54}\right)$,

- investment property expenditures on physical culture $\left(X_{55}\right)$,

- total expenditures on transport and communications under a village council office fund $\left(X_{56}\right)$,

- total expenditures on culture and national heritage protection under a village council office fund $\left(X_{62}\right)$.

In order to construct a model describing the tested dependence a forward stepwise regression method was used (Larose, 2012).

The initial selection of independent variables indicated the significance (at a significance level of 0.1 ) of the following independent variables:

- building permits and submissions with a construction project $\left(X_{71}\right)$,

- expenditures under the Waste disposal in cities and villages chapter $\left(X_{46}\right)$,

- total expenditures on health care $\left(X_{17}\right)$,

- social welfare benefits for natural persons $\left(X_{28}\right)$, 
- total expenditures on social assistance $\left(X_{25}\right)$,

- investment property expenditures on municipal services management and environmental protection $\left(X_{44}\right)$,

- expenditures on street, squares and roads lighting $\left(X_{48}\right)$,

- expenditures under the chapter Foster families $\left(X_{39}\right)$,

- total property expenditures on school system and education $\left(X_{15}\right)$,

- investment property expenditures on physical culture $\left(X_{55}\right)$,

- total expenditures on physical culture $\left(X_{52}\right)$,

- investment property expenditures on public safety and health care $\left(X_{11}\right)$.

Variables are presented in order of the strength of their effect on the dependent variable.

The logistic models presented below have been estimated using the highest reliability method. The calculations were made using the Gretl program. The final selection of the models was based on McFadden R-square, the number of cases of 'correct prediction' and the statistical significance of the model parameters.

Table 2.

Model 1

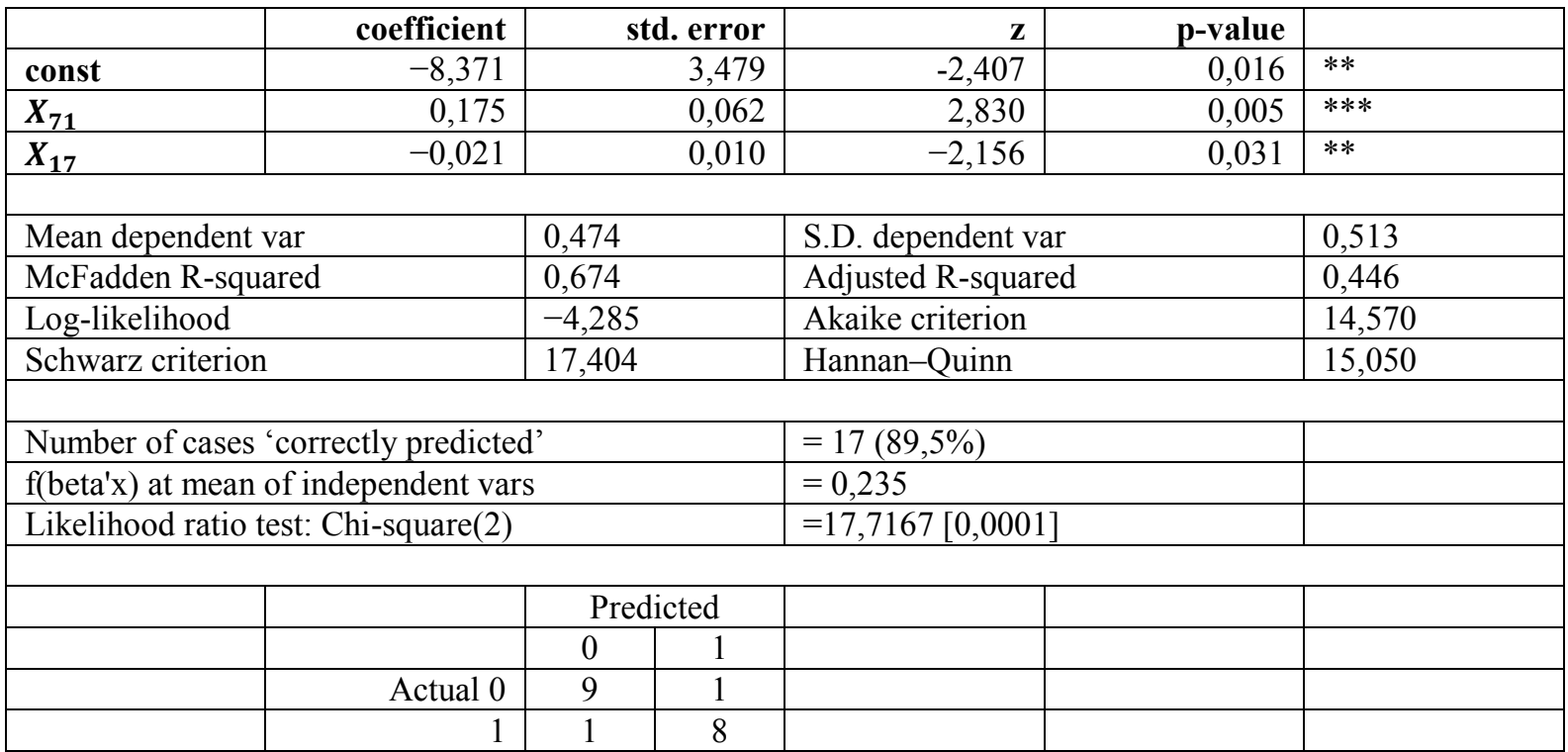

Source: authors' own elaboration.

Table 3.

Model 2

\begin{tabular}{|c|c|c|c|c|c|}
\hline & coefficient & std. error & $\mathbf{Z}$ & p-value & \\
\hline const & 4,897 & 1,887 & 2,595 & 0,010 & $* * *$ \\
\hline$X_{46}$ & $-0,087$ & 0,035 & $-2,454$ & 0,014 & $* *$ \\
\hline$X_{28}$ & $-0,045$ & 0,017 & $-2,674$ & 0,008 & $* * *$ \\
\hline \multicolumn{2}{|c|}{ Mean dependent var } & 0,474 & \multicolumn{2}{|c|}{ S.D. dependent var } & 0,513 \\
\hline \multicolumn{2}{|c|}{ McFadden R-squared } & 0,357 & \multicolumn{2}{|c|}{ Adjusted R-squared } & 0,129 \\
\hline \multicolumn{2}{|c|}{ Log-likelihood } & $-8,449$ & \multicolumn{2}{|l|}{ Akaike criterion } & 22,897 \\
\hline \multicolumn{2}{|c|}{ Schwarz criterion } & 25,731 & \multicolumn{2}{|l|}{ Hannan-Quinn } & 23,377 \\
\hline
\end{tabular}


Cont. table 3.

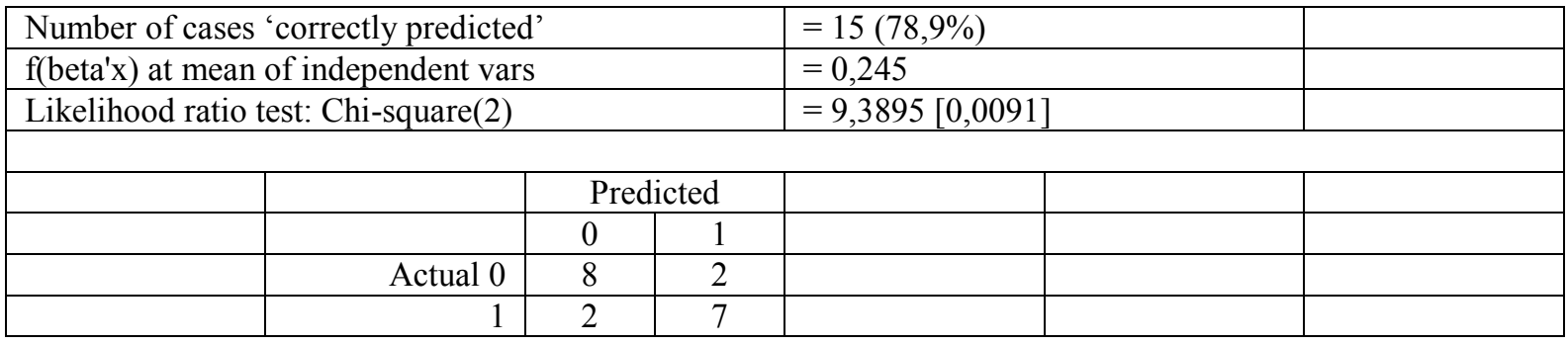

Source: authors' own elaboration.

Table 4.

Model 3

\begin{tabular}{|c|c|c|c|c|c|c|}
\hline & coefficient & \multicolumn{2}{|c|}{ std. error } & \multicolumn{2}{|r|}{ p-value } & \\
\hline const & $-0,547$ & & 0,909 & $-0,601$ & & \\
\hline$X_{46}$ & $-0,161$ & & 0,085 & $-1,890$ & * & \\
\hline$X_{44}$ & 0,013 & & 0,007 & 1,876 & * & \\
\hline \multicolumn{2}{|c|}{ Mean dependent var } & \multicolumn{2}{|l|}{0,474} & \multicolumn{2}{|c|}{ S.D. dependent var } & 0,513 \\
\hline \multicolumn{2}{|c|}{ McFadden R-squared } & \multicolumn{2}{|l|}{0,456} & \multicolumn{2}{|c|}{ Adjusted R-squared } & 0,227 \\
\hline \multicolumn{2}{|c|}{ Log-likelihood } & \multicolumn{2}{|l|}{$-7,154$} & \multicolumn{2}{|l|}{ Akaike criterion } & 20,307 \\
\hline \multicolumn{2}{|c|}{ Schwarz criterion } & \multicolumn{2}{|l|}{23,141} & \multicolumn{2}{|l|}{ Hannan-Quinn } & 20,787 \\
\hline \multicolumn{4}{|c|}{ Number of cases 'correctly predicted' } & \multicolumn{2}{|l|}{$=16(84,2 \%)$} & \\
\hline \multicolumn{4}{|c|}{$\mathrm{f}($ beta'x) at mean of independent vars } & \multicolumn{2}{|l|}{$=0,240$} & \\
\hline \multicolumn{4}{|c|}{ Likelihood ratio test: Chi-square(2) } & \multicolumn{2}{|l|}{$=11,980[0,0025]$} & \\
\hline & & \multicolumn{2}{|c|}{ Predicted } & & & \\
\hline & & 0 & 1 & & & \\
\hline & Actual 0 & 9 & 1 & & & \\
\hline & 1 & 2 & 7 & & & \\
\hline
\end{tabular}

Source: authors' own elaboration.

Table 5.

Model 4

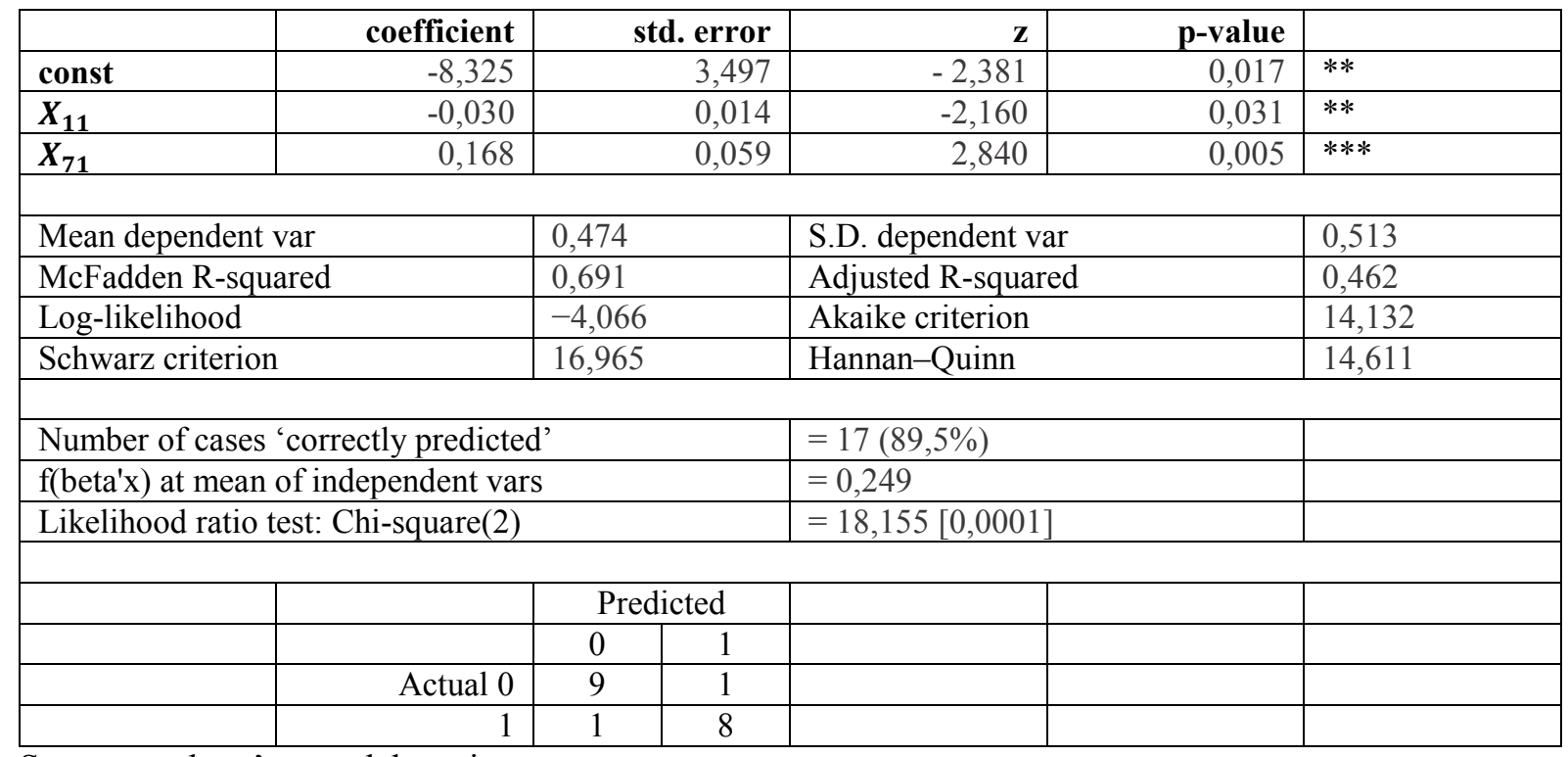

Source: authors' own elaboration. 
The estimated models allow to formulate conclusions regarding the influence of particular independent variables on the diagnosed level of quality of life in the studied communes with the assumption of fixed values of the other variables. In order to interpret the obtained forms of models, the concept of odds ratio (OR) was used. The odds ratio is defined as the ratio of the odds of success in two groups:

$$
O R=\frac{p_{1}}{1-p_{1}} \frac{1-p_{2}}{p_{2}}
$$

where $p_{i}$ is the probability of an event in the i-th observation class.

When analyzing model 1 , one should note that the increase in the number of building permits and submissions with a construction project $\left(X_{71}\right)$ by 1 p.p. results in an increase in the quality of life by an average of $19 \%\left(O R\left(X_{71}\right)=e^{0,175}=1,191\right)$. It indicates an increase in the attractiveness of the municipality as a place of residence. It may be caused by the influx of new residents, favorable demographic processes regarding the natural movement of the population and/or the increase in the residents' wealth. In turn, the increase in total health care expenditures $\left(X_{17}\right)$ by a unit, i.e. PLN 1 per capita, reduces the odds ratio by about $2 \%$ $\left(O R\left(X_{17}\right)=e^{-0,021}=0.980\right)$. As the increase in expenditures is related to the worsening health of the local community, both the factors comprising this category of expenditures and the reasons causing the worsening health of the population should be further analyzed.

Model 2. The value of the parameter for the variable expenditures under the chapter Waste disposal in cities and villages $\left(X_{46}\right)$ indicates that the odds of a high quality of life $\left(Z_{t}=1\right)$ if the value of the variable $X_{46}$ increases by a unit (i.e. PLN 1 per capita) will decrease by more than $8 \%$. Similarly, an increase in social welfare benefits for natural persons $\left(X_{28}\right)$ causes a decrease in the odds by about $4 \%$. The increase in expenditures in both areas indicates the existence of negative practices of residents of the municipality in terms of managing their own resources and public property and taking care of the local environment.

Model 3. The obtained results confirm the negative impact of the increase in expenditures on Waste disposal in cities and villages on the odds of a high level and quality of life. On the other hand, the increase in investment property expenditures in the section Municipal services management and environmental protection $\left(X_{44}\right)$ by a unit (i.e. PLN 1 per capita) changes the odds of improving the quality of life by about $1.3 \%$.

Model 4. The model again identifies a significantly positive impact of the variable $X_{71}$ on improving the quality of life in the municipality. Increase in the value of the variable investment property expenditures in the Public security and fire protection chapter $\left(X_{11}\right)$ by a unit, i.e. PLN 1 per capita, reduces the analyzed odds ratio by about $3 \%\left(O R\left(X_{11}\right)=\right.$ $\left.e^{-0,030}=0.970\right)$. Similarly to model 3 , the results obtained indicate that property and investment expenditures, by their nature, do not result in an immediate improvement of indicators of quality of life - their effects are visible in a longer time horizon. 
Estimated models are characterized by both good fit and high accuracy of predictions. The percentage of accurate predictions is $89.5 \%, 78.9 \%, 84.2 \%$ and $89.5 \%$ respectively.

\section{Conclusions}

The issue of the quality of life addressed in the article is extremely important and is reflected both in official statistical surveys and the work of individual researchers. However, it is worth emphasizing that due to the multi-faceted nature of the studied phenomenon, the results presented in the literature are not always comparable.

The methodological approach adopted in the paper combines the concept of the level of living and quality of life. On the basis of the Statistics Poland data, the TMR indicator for quality of life was constructed, which made it possible to identify four groups of municipalities that significantly differ in their socio-economic development. The next stage of the survey was to construct models of the qualitative independent variable which made it possible to indicate the most significant expenditures of the municipality having an impact on the quality of life of its residents, i.e.: building permits and submissions with a construction project, expenditures under the Waste disposal in cities and villages chapter, total expenditures on health care, social welfare benefits for natural persons, investment property expenditures on municipal services management and environmental protection, investment property expenditures on public safety and health care.

The obtained results confirm the significance of the influence of decisions of local governments on the quality of life of the residents. Public expenditures are a response to the needs of society. Many of them are long-term in nature, hence the social benefits observed in one year are on a rather small scale. One should also be aware that expenses incurred in one direction limit the possibilities of financing other categories of residents' needs.

The analysis presented in the article does not fully exhaust the subject matter, and the discussion covers only its selected aspects. The authors plan to conduct further research with the use of panel data models, which will allow to examine the impact of investment expenditures over a longer period of time. 


\section{References}

1. Brzozowska-Rup, K., Bednarczyk, J. (2018). Strategia bezpośredniego celu inflacyjnego NBP a wzrost gospodarczy w Polsce w latach 2005- 2017. Studia i Materialy "Miscellanea Oeconomicae".

2. Cieślik, E. (2008). Wybrane alternatywne sposoby mierzenia poziomu rozwoju gospodarczego. Equilibrium, nr 1-2(1). Toruń: Wydawnictwo Naukowe Uniwersytetu Mikołaja Kopernika.

3. Danieluk, B. (2010). Zastosowanie regresji logistycznej w badaniach eksperymentalnych. Psychologia Społeczna.

4. David Hosmer, S.L. (2000). Applied Logistic Regression, Wiley Series in Probability and Statistics. New York-Chichester-Weinheim-Brisbane-Singapore-Toronto: John Wiley \& Sons.

5. Główny Urząd Statystyczny (2017). Jakość życia w Polsce. Edycja 2017. Warszawa: Zakład Wydawnictw Statystycznych.

6. Gotowska, M. (2013). Współczesne uwarunkowania poziomu i jakości życia ludzi w Polsce. Bydgoszcz: Wydawnictwa Uczelniane Uniwersytetu Technologiczno-Przyrodniczego.

7. GUS, Bank Danych Lokalnych, Available: https://bdl.stat.gov.p1/BDL/start.

8. Kałamucka, W. (2007). Przydatność wskaźników jakości życia w ocenach warunków życia na potrzeby planowania przestrzennego, Waloryzacja środowiska przyrodniczego w planowaniu przestrzennym. Gdańsk: Fundacja Rozwoju Uniwersytetu Gdańskiego.

9. Kozera, A., Kozera, C. (2011). Poziom życia ludności i jego zróżnicowanie w krajach Unii Europejskiej. Journal of Agribusiness and Rural Development.

10. Larose, D.T. (2012). Metody i modele eksploracji danych. Warszawa: PWN.

11. Nowak, P. (2018). Zróżnicowanie jakości życia mieszkańców gmin wiejskich województwa świętokrzyskiego. Wiadomości Statystyczne.

12. Panek, T. (2007). Statystyka społeczna. Warszawa: PWE.

13. Peletewicz, M., Drabowicz, T. (2016). Jakość życia - globalnie i lokalnie. Pomiar $i$ wizualizacja. Łódź: Katedra Socjologii Ogólnej Wydział Ekonomiczno-Socjologiczny, Uniwersytet Łódzki.

14. Sompolska-Rzechuła, A. (2017). Przestrzenne zróżnicowanie poziomu jakości życia w Polsce. Wiadomości Statystyczne.

15. Urząd Statystyczny w Kielcach (2016). Sytuacja społeczno-gospodarcza Kielc w latach 2010-2015. Kielce: Urząd Statystyczny.

16. Włodarczyk, K. (2015). Jakość życia postrzegana przez Polaków w XXI wieku. Konsumpcja i Rozwój.

17. Wnuk, M. et al. (2013). Przegląd koncepcji jakości życia w naukach społecznych. Hygeia Public Health. 